Rev. Daniel Dzikiewicz

\title{
The Dogmatic Constitution on the Church Lumen Gentium and Interpretation of Lk 1, 34 as the Expression of the Vow of the Eternal Virginity of Mary
}

In 2015 it was celebrated the 50th Anniversary of the end of the Second Vatican Council. In this way the Church wanted to emphasize the importance of the documents published by the Council fathers. The article below has a similar purpose. Therein is intended to show how some of the Lumen gentium Constitution matters, which is one of the most important dogmatic Vaticanum II documents, can influence interpretation of the biblical text. This will be illustrated on the basis of the pericope of Lk 1, 34. According to the so-called traditional hypothesis, Mary's question is an expression of her eternal vow of virginity. Today, however, many scientists deny such an interpretation. Others, on the contrary, defend it. The discussion continues. Probably the aforementioned Constitution suggests some solution in this matter. And if it is so, then this document has not only a high dogmatic value but also an exegetical value.

Key words: Second Vatican Council, Dogmatic, Exegesis, Mariology, Mary's vow of virginity, Eve, Adam, Christ, St. Irenaeus.

\section{Preface}

Vaticanum Secundum (1962-1965) adopted sixteen different types of documents, including the Dogmatic Constitution on the Church 
Biblical theology

Lumen gentium (18 XI 1964)1. This is one of the most important papers of Vatican $\mathrm{II}^{2}$. Its importance is particularly evident in the field of ecclesiology. So important issues to the Church, such as: the mystery of the people of God (no. 1-17), the hierarchical structure of the Church (no. 18-29), the concept of laymen (no. 30-38) etc. are discussed in it $^{3}$.

But this paper is also significant for the Bible science. And not only because of the abundance in it of biblical texts (a total of 431 citations) that emphasize the biblical character of modern ecclesiology and show the close relationship between theology and exegesis ${ }^{4}$. The influence of Lumen gentium on the hermeneutics and the exegesis of the Holy Scripture goes far further, it is even able to help solve some of the biblical enigmas.

This article seeks to illustrate the latter statement with one example from the Gospel of Luke, chapter 1, verse 34. To achieve this goal, it was decided to divide this paper into two parts. The first part briefly presents the interpretation of verse Lk 1, 34, in the key of the eternal vows of virginity and the second suggests a critical evaluation of this hypothesis in the light of the theological statement of the Blessed Virgin Mary with the first woman - Eve, which is outlined in the Constitution Lumen gentium. The conclusions of the analysis are presented at the end of this elaboration. For the implementation of these tasks the methods of analysis, synthesis and interpretation of scientific exegesis-theological literature are used.

1 Cf. J. Erbacher, Der Vatikan: das Lexikon, Leipzig 2009, p. 442-445; R. Petraitis, Vatikano susirinkimai, in: R. Petraitis (ed.), Religijotyros žodynas, Vilnius 1991, p. 395 .

2 "Konstytucja Lumen gentium [...] podstawowym i centralnym dokumentem Soboru Watykańskiego II [...]" (E. Florkowski, Wprowadzenie do Konstytucji dogmatycznejo Kościele, in: Sobór Watykański II. Konstytucje, dekrety, deklaracje. Tekst polski, Poznań $1967^{3}$, p. 92); cf. A. Acerbi, Lumen gentium, in: W. Kasper - ed al. (ed.), Lexikon für Theologie und Kirche, vol. 4, Freiburg $1997^{3}$, p. 1119; J. Erbacher, Der Vatikan..., op. cit., p. 442; E. Florkowski, Wprowadzenie..., op. cit., p. 92; T. Lane, A Concise History of Christian Thought, Grand Rapids 20072, p. 312 .

3 "Konstytucja [...] stanowi niezwykle skondensowaną i bogatą w treść syntezę nauki o Kościele [...]" (E. Florkowski, Wprowadzenie..., op. cit., p. 92); cf. A. Acerbi, Lumen..., op. cit., p. 1119; J. Erbacher, Der Vatikan..., op. cit., p. 442; H. F. Fischer, Bažnyčia, nušviesta Vatikano II susirinkimo, in: V. Balčius - ed al. (eds.), Kunigas. Vilniaus Arkivyskupo Kardinolo Audrio Juozo Bačkio tarnystès penkiasdešimtmečiui, Vilnius 2011, p. 107-118; E. Florkowski, Wprowadzenie..., op. cit., p. 92-93.

4 "Uderzającą cechą dokumentu jest [...]jego biblijność [...]" (E. Florkowski, Wprowadzenie..., op. cit., p. 92); cf. A. Acerbi, Lumen..., op. cit., p. 1119; E. Florkowski, Wprowadzenie..., op. cit., p. 92-93. 


\section{The verse Luke 1, 34 and the hypothesis of the eternal vow of Mary's virginity}

Human is the creature that questions - homo interrogans ${ }^{5}$. The Mother of the Lord Jesus Christ was no exception in this regard. She also asked questions. The authors of the New Testament wrote two

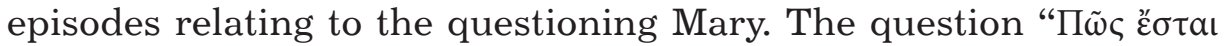

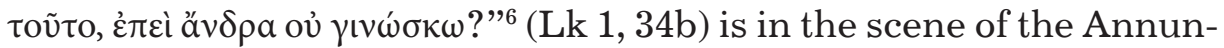

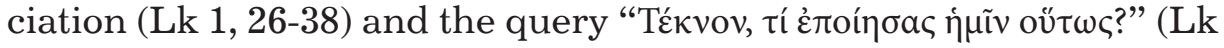
$2,48 \mathrm{~b}$ ) is in the narration about finding the twelve-year-old Jesus in the temple (Lk 2, 41-52).

On the one hand, it is like a drop in the sea, Mary probably asked a lot more questions in her life, but on the other hand, maybe it's better that only two of her statements were registered, because if the unsaved ones would have had a similar degree of difficulty, then such a strenuous work of exegetes would become even more difficult ${ }^{7}$. And indeed, these are two questions that can be directly included in the texts marked as crux interpretum ${ }^{8}$. This applies especially to the first question (Lk 1,34) mentioned during the visit of Angel Gabriel to Nazareth (Lk 1, 26-38), which - once expressed - inevitably gave rise to another query, namely: quisnam sit sensus questionis Mariae - what is the sense of the Mary's question? ${ }^{9}$.

Cf. H. U. von Balthasar, W petni wiary, Kraków 1991, p. 79-80.

All Greek-language Bible quotes come from Novum Testamentum Graece, Nestle-Aland (eds.), Stuttgart $1999^{27}$.

Cf. Papieska Komisja Biblijna, Natchnienie i prawda Pisma świętego. Słowo, które od Boga pochodzi i mówi o Bogu, aby zbawić świat, Kielce 2014, p. 177.

"[U]na dichiarazione che ha fatto versare fiumi d'inchiostro [...]" (G. Ravasi, Videro il Bambino e sua Madre. Meditazioni sui vangeli dell'infanzia, Collana «Le Àncore», Milano $2000^{4}$, p. 81); cf. D. Dikevičius, Bibliné Rožinio slépiniu prasmé, „Artuma. Katalikiškas mėnraštis šeimai“, 2008, no. 1, p. 5; D. Dzikiewicz, Łk 1,34 a obraz Matki Bożej Ostrobramskiej, in: D. Dzikiewicz - J. Witkowski (eds.), Anna Krepsztul-człowiek sztuki i cierpienia. Księga pamiątkowa dedykowana Pani Annie Krepsztul w 80. rocznicę urodzin i 5. rocznicę śmierci, Wielcy Ludzie Wileńszczyzny 2, Wilno 2012, p. 88; F. Mickiewicz, Ewangelia wedtug świętego Łukasza rozdziaty 1-11. Wstęp, przekład z oryginatu, komentarz, Nowy Komentarz Biblijny Nowy Testament III/1, Częstochowa 2011, p. 115; Z. Ziółkowski, Najtrudniejsze stronice Nowego Testamentu, Biblioteka Miłośników Biblii, Warszawa 2006, p. 52-58.

9 Cf. P. F. Ceuppens, Theologia biblica. De Mariologia Biblica, vol. 4, Rome 1948, p. 73; D. Dzikiewicz, Ocena krytyczna hipotezy przedanuncjacyjnego ślubu wiekuistego dziewictwa Maryi, Dolnośląska Biblioteka Cyfrowa, Wrocław 2014, p. 290. 
Biblical theology

So what is the meaning of the question of Mary? Nowadays, biblical scholars calculate about 20 different solutions ${ }^{10}$. The most famous of them, called the interpretation of the eternal vow of virginity, states: "This question in the bride's lips suggests that Mary and Joseph decided to live a life of innocence"11.

This is one of the oldest interpretations of passage Lk 1, 34. Its' roots come from the times of the Protoevangelium of James - dated to about the middle of the second century ${ }^{12}$. Among her first followers there were such outstanding personalities of the Church as St. Gregory of Nyssa (c. 330-395 $)^{13}$ and St. Augustine of Hippo $(354-430)^{14}$. Among Lithuanian biblical scholars, it was represented, for example, by the Rev. Bishop J. J. Skvireckas (1873-1959), Rev. Msgr. L. Tulaba (1912-2002) and by the philosopher prof. A. Maceina (1908-1987) ${ }^{15}$.

Nevertheless, recently the interpretation of the vows of eternal virginity began to lose its position. Instead, new solutions are proposed. Among them, the literary hypothesis and the solution of premarital

$10 \quad$ Cf. D. Dzikiewicz, Ocena..., op. cit., p. 3-4,

$11 \quad$ Naujasis Testamentas, Č. Kavaliauskas - V. Aliulis (eds.), Salzburg 1989², p. 149; cf. D. Dikevičius, Biblinė..., op. cit., p. 5; D. Dzikiewicz, Łk 1,34..., op. cit., p. 88; D. Dzikiewicz, Ocena..., op. cit., p. 4; F. Mickiewicz, Ewangelia..., op. cit., p. 115116; Šventasis Raštas Naujojo Testamento. Keturios evangelijos ir Apaštalu darbai, vol. 1, L. Tulaba (ed.), Roma 1979, p. 249.

12 Cf. D. Dzikiewicz, Łk 1,34..., op. cit., p. 93-94; D. Dzikiewicz, Ocena..., op. cit., p. 61-65; E. A. Livingstone, The Concise Oxford Dictionary of the Christian Church, Oxford $2006^{2}$, p. 304 .

13 Cf. Gregorius Nyssenus, In diem Natalem Christi, in: Enchiridion marianum biblicum patristicum, D. Casagrande (ed.), Rome 1974, p. 320-325; D. Dzikiewicz, Ocena..., op. cit., p. 6.

14 Cf. Aurelius Augustinus, De Sancta Virginitate. Liber unus, in: Sancti Aurelii Augustini, Hipponensis Episcopi, opera omnia, J. P. Migne (ed.), Patrologiae cursus completus Series Latina 40, vol. 6, Paris 1861, IV. 4; J. Ratzinger Benedikt XVI, Jesus von Nazareth. Prolog. Die Kindheitsgeschichten, Freiburg 2013, p. 45; D. Dzikiewicz, Ocena..., op. cit., p. 6.

15 Cf. D. Dzikiewicz, Łk 1,34..., op. cit., p. 88-92; A. Maceina, Didžioji Padéjejja, in: A. Maceina, Raštai. Teologinès-filosofinès studijos, Iš Lietuvos filosofijos palikimo 4, Vilnius 1994, p. 402-405; Šventasis Raštas Naujojo Testamento, J. J. Skvireckas (ed.), Nördlingen $1949^{2}$, p. 303; Šventasis Raštas Naujojo Testamento. Keturios evangelijos ir Apaštalu darbai, vol. 1, L. Tulaba (ed.), Roma 1979, p. 249. 
sexual abstinence are particularly popular ${ }^{16}$. This phenomenon also occurs among Lithuanian exegetes ${ }^{17}$.

But, on the other hand, it must be admitted that in the camp of supporters of interpreting the eternal vows of virginity, time is also not wasted: new arguments are sought (for example, an argument from the Hebrew wording of the text Lk 1, 34) ${ }^{18}$, new words are being developed (for example, instead of the words vow of virginity are proposed words subconscious desire of virginity $)^{19}$ etc. In other words, the debate is taking place and its final point has not yet been achieved ${ }^{20}$.

\section{Lumen gentium's Eve-Mary's typology and interpretation of $\mathrm{Lk} \mathrm{1,} 34$ in the key of virginal vows}

If then the discourse is still being developed, it would be desirable to contribute to it with the help of the Constitution of the Lumen gentium, and in particular its text, which finds the motive of comparison between Eve and Mary. This passage sounds like the following:

Rightly therefore the holy Fathers see her as used by God not merely in a passive way, but as freely cooperating in the work of human salvation through faith and obedience. For, as St. Irenaeus says, she ,being obedient, became the cause of salvation for herself and for the whole human race." Hence not a few of the early Fathers gladly assert in their preaching, ,The knot of Eve's disobedience was untied by Mary's obedience; what the virgin Eve bound through her unbelief, the Virgin Mary loosened by her faith." Comparing Mary with Eve, they call her ,the Mother of the living," and still more often they say: „death through Eve, life through Mary"21.

The text deals with the cooperation of the Blessed Virgin Mary in the history of Salvation. The main hallmarks of this synergism are

16 Cf. F. Mickiewicz, Ewangelia..., op. cit., p. 115-116; J. Ratzinger Benedikt XVI, Jesus..., op. cit., p. 45; D. Dzikiewicz, Ocena..., op. cit., p. 4.71-78.

17 Cf. D. Dikevičius, Biblinè..., p. 5; D. Dzikiewicz, Łk 1,34..., op. cit., p. 87-95; D. Dzikiewicz, Ocena..., op. cit., p. 76.

18 Cf. J. M. García Pérez, M. Herranz Marco, La infancia de Jesús según Lucas, Madrid 2000, p. 39-40; D. Dzikiewicz, Ocena..., op. cit., p. 22-23.

19 Cf. R. Guardini, La Madre del Signore. Una lettera, Opere di Romano Guardini, Brescia 1997², p. 27-28; D. Dzikiewicz, Ocena..., op. cit., p. 91.

20 "So bleibt das Rätsel - oder vielleicht sagen wir besser: das Geheimnis - dieses Satzes bestehen" (J. Ratzinger Benedikt XVI, Jesus..., op. cit., p. 45).

21 Second Vatican Council, Dogmatic Constitution on the Church Lumen gentium, no. 56, http://www.vatican.va/archive/hist_councils/ii_vatican_council/ documents/vat-ii_const_19641121_lumen-gentium_en.html. 
Biblical theology the obedience of Mary $(\operatorname{Lk} 1,38)$ and her faith $(\operatorname{Lk} 1,45)^{22}$. Thanks to them, she has become not only the Mother of the Son of God (Lk 2,1-7) and of the Church (Jn 19, 25-27), but also Eve's antitype, transforming the name of the perpetrator of sin EVA into a joyful greeting of AVE, symbolically expresses the idea of salvation of fallen humanity. The letter "A" represents here the Latin prefix $a b$, which means separation and the letters of the "VE" refer to the Latin noun vae meaning grief, misfortune and misery, thus one of the main consequences of the birth $\sin (\text { Gen } 3,16-19)^{23}$.

Admittedly, the fathers of Council did not invent the antithesis of Eve-Mary. Usually the initiator of this antithesis is considered to be St. Justin Martyr (c. 100-165) - a philosopher and apologist ${ }^{24}$ - who, when writing The Dialogue with Trypho the Jew, had an idea, most likely under the influence of the texts of Rom 5, 14 and 1 Cor 15, 22.45, to juxtaposing the most influential women of humanity Eve and Mary ${ }^{25}$. The popularization of this idea and the deepening of its theological content are attributed to St. Irenaeus of Lyons (c. 130-200) - the father of Catholic Dogmatic and the first Mariologist of the Church ${ }^{26}$. It is written in one of his most significant works - Adversus haereses ${ }^{27}$ :

Cf. G. Miegge, La Vergine Maria. Saggio di storia del dogma, Torino $2008^{3}$, p. 262.

Сf. И. Х. Дворецкий, Латинско-русский словарь, Москва 2000, p. 11.803; A. Klawek, Ave Maria, „Ruch Binlijny i Liturgiczny“, 1951, no. 4, p. 36; J. Pelikan, Mary Through the Centuries. Her Place in the History of Culture, New Haven 1996, p. 44.

Cf. R. Laurentin, Matka Pana. Krótki traktat teologii maryjnej. Wydanie integralne, Theotokos Seria mariologiczna 1, Warszawa 1989, p. 65; E. A. Livingstone, The Concise..., op. cit., p. 325.

Some authors see some germs of the given antithesis also in the image of $\mathrm{Ma}-$ ry-woman of the Gospel according to St. John $(2,4 ; 19,26)$; cf. R. Laurentin, Matka..., op. cit., p. 65.

Cf. T. Lane, A Concise..., p. 12-14; E. A. Livingstone, The Concise..., op. cit., p. 300; J. Pelikan, Mary..., op. cit., p. 42; C. Trevett, Ireneusz, in: R. J. Coggins, J. L. Houlden (eds.), Stownik hermeneutyki biblijnej, Prymasowska Seria Biblijna, Warszawa 2005, p. 335-336; H. U. von Balthasar, W petni..., op. cit., p. 536; B. Kochaniewicz, Antyteza Ewa-Maryja w Adversus haereses św. Ireneusza z Lyonu. Perspektywa apologetyczna, "Poznańskie Studia Teologiczne”, 2009, no. 23 , p. 89-91.

27 The threads of Eve-Mary antithesis are also found in the Armenian translation of the work Epideixis of St. Irenaeus (Demonstratio apostolicae praedicationis), found in the twentieth century; cf. J. Pelikan, Mary..., op. cit., p. 42; H. U. von Balthasar, W petni..., op. cit., p. 536. 
[...] Mary the Virgin is found obedient, saying, „Behold the handmaid of the Lord; be it unto me according to thy word." But Eve was disobedient; for she did not obey when as yet she was a virgin. And even as she, having indeed a husband, Adam, but being nevertheless as yet a virgin (for in Paradise ,they were both naked, and were not ashamed," inasmuch as they, having been created a short time previously, had no understanding of the procreation of children: for it was necessary that they should first come to adult age, and then multiply from that time onward), having become disobedient, was made the cause of death, both to herself and to the entire human race; so also did Mary, having a man betrothed [to her], and being nevertheless a virgin, by yielding obedience, become the cause of salvation, both to herself and the whole human race. And on this account does the law term a woman betrothed to a man, the wife of him who had betrothed her, although she was as yet a virgin; thus indicating the back-reference from Mary to Eve, [...]. For what the virgin Eve had bound fast through unbelief, this did the virgin Mary set free through faith ${ }^{28}$.

In this text, the author aligns two women: Mary and Eve. This is done on two levels. The first one gives rise to similarities, the second one gives rise to differences ${ }^{29}$.

The level of similarities. Two women are virgins (Maria virgo / Eva virgo), but already married (Eva virum habens / Maria habens virum). Eve's husband is named Adam (habens Adam), and Mary's spouse's name is not mentioned (praedestinatum virum). Both women are also very influential: Eve has become the cause of the death of all mankind (universal genero humano), Mary - of the salvation (universe generi humano $)^{30}$.

The level of difference. On this level, two opposite provisions are evident: Eve's disobedience / unbelief (inobaudiens / per incredulitatem) contradicts Mary's obedience / faith (obaudiens / per fidem), and the

$28 \quad$ Irenaeus of Lyons, Against Heresies. Book III, 22.4, http://www.earlychristianwritings.com/text/irenaeus-book3.html; cf. Irenäus von Lyon, Adversus haereses. Gegen die Häresien. Griechisch. Lateinisch. Deutsch, Fontes Christiani 8/3, Freiburg 1995, p. 278-281; Ireniejus Lionietis, Prieš erezijas, in: Bažnyčios Tévai. Nuo Apaštališkuju Tèvu iki Nikèjos Susirinkimo. Antologija, D. Alekna - V. Ališauskas (eds.), Vilnius 2003, p. 250-251.

Cf. R. Laurentin, Matka..., op. cit., p. 66; B. Kochaniewicz, Antyteza..., op. cit., 97-100.

30 Cf. Irenaeus of Lyons, Against..., op. cit., 22.4, http://www.earlychristianwritings. com/text/irenaeus-book3.html; Irenäus von Lyon, Adversus..., op. cit., p. 278-281; Ireniejus Lionietis, Prieš..., op. cit., p. 250-251. 
Biblical theology

death, evoked by Eve (causa facta est mortis) - the salvation brought by Mary (causa facta est salutis) ${ }^{31}$.

And what does this have to do with the interpretation of verses Lk 1,34 in the key to the vow of the eternal virginity of Mary? At first glance - nothing! However, it is only from the first point of view, because a more accurate analysis of the text allows one to notice another element of Eve-Mary's antithesis, namely the fact that St. Irenaeus not only mentions the virginity of these two women, but also explains the cause of this status quo.

The basis of Eve's virginity was her own and her husband sexual immaturity; it indicates, as St. Irenaeus explains, the lack of feeling of shame (Gen 2, 25):

they were both naked, and were not ashamed, in as much as they, having been created a short time previously, had no understanding of the procreation of children $[\ldots]^{32}$.

And what is the basis of Mary's virginity? It will sound strange, but St. Irenaeus Mary's virginity justifies only with a biblical text (Deut 22, 23-24) that refers to the marital tradition of ancient Israelites:

And on this account does the law term a woman betrothed to a man, the wife of him who had betrothed her, although she was as yet a virgin ${ }^{33}$.

This tradition - which St. Irenaeus has in mind - foresaw a two-step marriage. First a formal marriage took place, and then, more or less after a year, the wife was introduced to her husband's home. Admittedly, during the first phase, the spouses lived separately and did not have sexual intercourse, especially in Galilee ${ }^{34}$, but nevertheless they were real spouses who could only be separated by the death of one of

$31 \quad$ Cf. Irenaeus of Lyons, Against..., op. cit., 22.4, http://www.earlychristianwritings. com/text/irenaeus-book3.html; Irenäus von Lyon, Adversus..., op. cit., p. 278-281; Ireniejus Lionietis, Prieš..., op. cit., p. 250-251.

Irenaeus of Lyons, Against..., op. cit., 22.4, http://www.earlychristianwritings. com/text/irenaeus-book3.html; cf. Irenäus von Lyon, Adversus..., op. cit., p. 278-281; Ireniejus Lionietis, Prieš..., op. cit., p. 250-251.

Irenaeus of Lyons, Against..., op. cit., 22.4, http://www.earlychristianwritings. com/text/irenaeus-book3.html; cf. Irenäus von Lyon, Adversus..., op. cit., p. 278-281; Ireniejus Lionietis, Prieš..., op. cit., p. 250-251.

„According to b. Ketub. 12a, pre-marital intimacy between a betrothed couple was permitted in Judaea but not in Galilee [...]" (M. Goodman, Galilean Judaism and Judaean Judaism, in: W. Horbury, W. D. Dawies, J. Sturdy (eds.), The Cambridge History of Judaism. The Early Roman Period, vol. III, Cambridge 2008, p. 596); cf. D. Dzikiewicz, Ocena..., op. cit., p. 135. 
the spouses or an official divorce ${ }^{35}$. It was in such a marital situation that Mary was at the Annunciation in Nazareth (Lk 1, 26-27). She was after marriage, but before she was introduced to her husband's home (Mt 1, 18-25).

In other words, the justification for Mary's virginity, as given by St. Irenaeus, has nothing to do with her vows of eternal virginity. Of course, immediately the question arises: why? The range of possible answers would probably be quite broad: he did not know, did not want to, could not, did not agree, did not support etc. Whatever the case, the fact remains a fact - the above-mentioned work of St. Irenaeus does not confirm the vow of Mary's virginity. But not only because there was no such a thing or that he was nor aware about it's existence. The real reason for this was probably different, and namely, Eve-virgin's openness to motherhood: "So God created humankind [...] male and female he created them. [...] and God said to them: Be fruitful and multiply [...]"36 (Gen 1, 27-28); "The man named his wife Eve, because she was the mother of all living" (Gen 3, 20).

So Mary-virgin should have a similar nature. Otherwise, Eve-Mary's parallel would lose one of the main signs of parallelism and cease to function at all. Indeed, for each typology, the continuity of its essential elements is necessary ${ }^{37}$. In turn, the interpretation of fragment Lk 1, 34 in the key of the oath of eternal virginity, which Mary performed before the Annunciation in Nazareth, removes her openness to motherhood, and at the same time destroys the typology of Eve-Mary.

Something similar could be deduced from the typology of AdamChrist, which is also found on the pages of the cited above work of St. Irenaeus:

For as by one man's disobedience sin entered, and death obtained [a place] through sin; so also by the obedience of one man, righteousness having been introduced, shall cause life to fructify in those persons who in times past were dead. And as the protoplast himself Adam, had his substance from untilled and as yet virgin soil [...], and was formed by the hand of God, that is, by the Word of God, for "all things were made by Him," and the Lord took dust from the earth and formed man; so did He who is the Word, recapitulating Adam in Himself, rightly

\footnotetext{
35 Cf. M. Rosik, Ziemia Stowa. Biblijny przewodnik po Ziemi Świętej. Izrael - Jordania - Synaj, Wrocław 2013, p. 54-59.

36 All English-language Bible quotes come from Holy Bible. New Revised Standard Version: Catholic Edition, London 1993.

$37 \quad$ Cf. C. Baldick, Oxford Dictionary of Literary Terms, Oxford 2008 ${ }^{3}$, p. 247.344; B. McNeil, Typologia, in: R. J. Coggins, J. L. Houlden (eds.), Stownik hermeneutyki biblijnej, Prymasowska Seria Biblijna, Warszawa 2005, p. 894.
} 
Biblical theology

receive a birth, enabling Him to gather up Adam [into Himself], from Mary, who was as yet a virgin ${ }^{38}$.

In the above text, St. Irenaeus, compares the supernatural beginnings of the first and second Adam. Both were conceived in a virginal way. The first was born from the virgin soil, the second from the virgin woman. But the soil God made the first man from (Gen 2, 7) was - as the Bishop of Lyon emphasized - not yet touched (Gen 2, 4-6), but in fact open to fertility and called to it (Gen 1, 9-11). Therefore, also the Virgin Mary - the equivalent of the virgin soil - should have, before the foretold of the birth of Jesus in Nazareth, also an analogous procreative orientation, because otherwise Adam-Christ parallelism would lose one of its most important elements.

Biblical Mary as a wife of Joseph was just such a person (Mt 1, 18; Lk 1, 26-27). The fundamental change in this matter was introduced much later only through the so-called apocryphal tradition, which from the biblical Mary, open to fertility, made the sworn virgin, closed to fertility.

\section{Recapitulation}

The Lumen gentium Constitution is one of the highest-ranking Vatican II documents. Its genesis was accompanied by a long and heated discussion ${ }^{39}$. So there is not a one meaningless or casual word in it. Eve-Mary's antithesis does not make any exceptions in this case. Invented by St. Justin Martyr and developed by St. Irenaeus, it became an integral part of Catholic theology, and even one of the main principles of Mariology ${ }^{40}$. This is evidenced by the inclusion of a given antithesis in the text of the Constitution Lumen gentium. And this in turn also affects the Catholic exegesis of Mariology texts. The pericope of Lk 1, 34 is a great example. The interpretation of a given verse in the key of vows of eternal virginity weakens the typology of Eve-Mary, because Eve, open to motherhood, could not be the perfect prototype of Mary, who, as the proponents of this hypothesis claim, vowed virginity, and vice versa, the woman from Nazareth, vowed to virginity and as so closed to motherhood, she could not be the perfect equivalent of Eve as the mother of all living. Therefore, the following conclusions are drawn: 1) the interpretation of verse Lk 1, 34 in the key of virginal vows, is theologically unjustified and as such should be

38 Irenaeus of Lyons, Against..., op. cit., 21.10, http://www.earlychristianwritings. com/text/irenaeus-book3.html; cf. Ireniejus Lionietis, Prieš..., op. cit., p. 247-248. 
abandoned; 2) The Constitution Lumen gentium opens up new theological perspectives, even in the field of biblical science ${ }^{41}$.

\section{KONSTYTUCJA DOGMATYCZNA O KOŚCIELE LUMEN GENTIUM A INTERPRETACJA ŁK 1, 34 JAKO WYRAZU ŚLUBU WIEKUISTEGO DZIEWICTWA MARYI}

Biblical theology

W 2015 roku obchodzono 50-tą rocznicę zakończenia obrad Soboru Watykańskiego II (1962-1965). W taki sposób chciano podkreślić znaczenie przyjętych przez Ojców Soborowych dokumentów. Niniejszy artykuł posiada analogiczny cel. Jego zadaniem jest ukazanie wpływu pewnych treści Konstytucji Dogmatycznej o Kościele Lumen gentium, jednego z najważniejszych dokumentów soborowych, na interpretację tekstów biblijnych. Dana teza jest zilustrowane na przykładzie wersetu Łk 1, 34. Zdaniem zwolenników tzw. hipotezy tradycyjnej ów werset stanowi wyraz przedanuncjacyjnego ślubu wiekuistego dziewictwa Maryi. Dzisiaj jednakże ta interpretacja traci na rankingu. Chociaż nie brakuje także jej adherentów. Toteż dyskusja trwa. Powyżej wspomniana Konstytucja sugeruje pewne rozwiązanie w tej kwestii. A jeżeli tak, to Lumen gentium posiada nie tylko wysoką wartość dogmatyczną, lecz także i egzegetyczną.

Słowa kluczowe: Sobór Watykański Il, dogmatyka, egzegeza, mariologia, ślub dziewictwa, Maryja, Ewa, św. Ireneusz.

\section{Bibliography:}

1. Acerbi A., Lumen gentium, in: W. Kasper - ed al. (eds.), Lexikon für Theologie und Kirche, vol. 4, Freiburg 1997³, p. 1118-1120.

2. Aurelius Augustinus, De Sancta Virginitate. Liber unus, in: Sancti Aurelii Augustini, Hipponensis Episcopi, opera omnia, J. P. Migne (ed.), Patrologiae cursus completus Series Latina 40, vol. 6, Paris 1861, p. 396-428.

3. Baldick C., Oxford Dictionary of Literary Terms, Oxford $2008^{3}$.

4. Ceuppens P. F., Theologia biblica. De Mariologia Biblica, vol. 4, Rome 1948.

5. Dikevičius D., Biblinè Rožinio slèpiniu prasmè, „Artuma. Katalikiškas mènraštis šeimai“, 2008, no. 1, p. 4-6.

6. Dzikiewicz D., Łk 1,34 a obraz Matki Bożej Ostrobramskiej, in: D. Dzikiewicz - J. Witkowski (eds.), Anna Krepsztul - człowiek sztuki i cierpienia. Księga pamiatkowa dedykowana Pani Annie Krepsztul w $80 . \quad$ Roczicę urodzin i 5. rocznicę śmierci, Wielcy Ludzie Wileńszczyzny 2, Wilno 2012, p. 87-95.

41 "[...] Lumen gentium [...] otwiera [...] niewątpliwie nowe perspektywy odrodzeniowe dla myśli teologicznej [...]” (E. Florkowski, Wprowadzenie..., op. cit., p. 93). 
Biblical theology
7. Dzikiewicz D., Ocena krytyczna hipotezy przedanuncjacyjnego ślubu wiekuistego dziewictwa Maryi, Dolnośląska Biblioteka Cyfrowa, Wrocław 2014.

8. Дворецкий И. Х., Латинско-русский словарь, Москва 2000.

9. Erbacher J., Der Vatikan: das Lexikon, Leipzig 2009.

10. Fischer H. F., Bažnyčia, nušviesta Vatikano II susirinkimo, in: V. Bulčius ed al. (eds.), Kunigas. Vilniaus Arkivyskupo Kardinolo Audrio Juozo Bačkio tarnystès penkiasdešimtmečiui, Vilnius 2011, p. 107-118.

11. Florkowski E., Wprowadzenie do Konstytucji dogmatycznej o Kościele, in: Sobór Watykański II. Konstytucje, dekrety, deklaracje. Tekst polski, Poznań $1967^{3}$, p. 89-104.

12. García Pérez J. M. - Herranz Marco M., La infancia de Jesús según Lucas, Studia Semitica Novi Testamenti 6, Madrid 2000.

13. Goodman M., Galilean Judaism and Judaean Judaism, in: W. Horbury - W. D. Dawies - J. Sturdy (eds.), The Cambridge History of Judaism. The Early Roman Period, vol. III, Cambridge 2008, p. 596-617.

14. Gregorius Nyssenus., In diem Natalem Christi, in: Enchiridion marianum biblicum patristicum, D. Casagrande (ed.), Rome 1974, p. 320-325.

15. Guardini R., La Madre del Signore. Una lettera, Opere di Romano Guardini, Brescia $1997^{2}$.

16. Holy Bible. New Revised Standard Version: Catholic Edition, London 1993.

17. Irenaeus of Lyons, Against Heresies. Book III, 22.4, http://www.earlychristianwritings.com/text/irenaeus-book3.html.

18. Irenäus von Lyon, Adversus haereses. Gegen die Häresien. Griechisch. Lateinisch. Deutsch, Fontes Christiani 8/3, Freiburg 1995.

19. Ireniejus Lionietis, Prieš erezijas, in: Bažnyčios Tèvai. Nuo Apaštališkuju Tèvu iki Nikejjos Susirinkimo. Antologija, D. Alekna - V. Ališauskas (eds.), Vilnius 2003, p. 229-266.

20. Klawek A., Ave Maria, „Ruch Binlijny i Liturgiczny“, 1951, no. 4, p. 25-37.

21. Kochaniewicz B., Antyteza Ewa-Maryja w Adversus haereses św. Ireneusza z Lyonu. Perspektywa apologetyczna, „Poznańskie Studia Teologiczne“, 2009, no. 23, p. 89-102.

22. Lane T., A Concise History of Christian Thought, Grand Rapids $2007^{2}$.

23. Laurentin R., Matka Pana. Krótki traktat teologii maryjnej. Wydanie integralne, Theotokos Seria mariologiczna 1, Warszawa 1989.

24. Livingstone E. A., The Concise Oxford Dictionary of the Christian Church, Oxford 2006 ${ }^{2}$.

25. Maceina A., Didžioji Padejjeja, in: A. Maceina, Raštai. Teologinès-filosofinès studijos, Iš Lietuvos filosofijos palikimo 4, Vilnius 1994, p. 349-494.

26. McNeil B., Typologia, in: R. J. Coggins - J. L. Houlden (eds.), Stownik hermeneutyki biblijnej, Prymasowska Seria Biblijna, Warszawa 2005, p. 894-895.

27. Mickiewicz F., Ewangelia wedtug świętego Łukasza rozdziaty 1-11. Wstęp, przektad z oryginatu, komentarz, Nowy Komentarz Biblijny Nowy Testament III/1, Częstochowa 2011.

28. Miegge G., La Vergine Maria. Saggio di storia del dogma, Piccola Biblioteca Teologica 93, Torino $2008^{3}$.

29. Naujasis Testamentas, Č. Kavaliauskas - V. Aliulis (eds.), Salzburg $1989^{2}$. 
30. Novum Testamentum Graece, Nestle-Aland (eds.), Stuttgart $1999^{27}$.

31. Papieska Komisja Biblijna., Natchnienie i prawda Pisma świętego. Stowo, które od Boga pochodzi i mówi o Bogu, aby zbawić świat, Kielce 2014.

32. Pelikan J., Mary Through the Centuries. Her Place in the History of Culture, New Haven 1996.

33. Petraitis R., Vatikano susirinkimai, in: R. Petraitis (ed.), Religijotyros Biblical žodynas, Vilnius 1991, p. 394-395.

34. Ratzinger Benedikt XVI J., Jesus von Nazareth. Prolog. Die Kindheitsgeschichten, Freiburg 2013.

35. Ravasi G., Videro il Bambino e sua Madre. Meditazioni sui vangeli dell'infanzia, Milano $2000^{4}$.

36. Rosik M., Ziemia Stowa. Biblijny przewodnik po Ziemi Świętej. Izrael Jordania - Synaj, Wrocław 2013.

37. Second Vatican Council, Dogmatic Constitution on the Church Lumen gentium, http://www.vatican.va/archive/hist_councils/ii_vatican_council/ documents/vat-ii_const_19641121_lumen-gentium_en.html.

38. Söll G., Eva-Maria-Parällele, in: R. Bäumer, L. Schêffczyk (eds.), Marienlexikon, vol. 2, St. Ottilien 1989, p. 420-421.

39. Šventasis Raštas Naujojo Testamento, J. J. Skvireckas (ed.), Nördlingen $1949^{2}$.

40. Šventasis Raštas Naujojo Testamento. Keturios evangelijos ir Apaštalu darbai, vol. 1, L. Tulaba (ed.), Roma 1979.

41. Trevett C., Ireneusz, in: R. J. Coggins, J. L. Houlden, Stownik hermeneutyki biblijnej, Prymasowska Seria Biblijna, Warszawa 2005, p. 335-337.

42. Von Balthasar H. U., W petni wiary, Kraków 1991.

43. Ziółkowski Z., Najtrudniejsze stronice Nowego Testamentu, Biblioteka Miłośników Biblii, Warszawa 2006. 